\title{
Origin, incidence and impact of droughts over India and remedial measures for their mitigation
}

\author{
D A MOOLEY
}

Indian Institute of Tropical Meteorology, Pune 411008, India

\begin{abstract}
The paper highlights the factors which tend to reduce the Indian monsoon rainfall substantially. These are: Eurasian snow accumulation during December-March, El Nino with warming phase of the eastern equatorial Pacific $\left[0-10^{\circ} \mathrm{S}, 80^{\circ} \mathrm{W}-180^{\circ} \mathrm{W}\right]$, long periods of 'break' in the monsoon and poor westward penetration of monsoon low-pressure systems.

Utilising the joint criteria based on specified threshold values of the percentage departure from normal for area-averaged Indian monsoon rainfall and of the percentage Indian area under deficient monsoon rainfall, the years of all-India drought have been identified. Enhancing these criteria suitably, years of severe and phenomenal droughts have also been identified. India experienced 18 droughts during 1871-1990, of which 10 were severe and 5 were phenomenal. While the periods $1901-20$ and 1961-80 had the highest frequency of drought, 1921-40 had no drought at all. Most of the severe, and all the phenomenal droughts, occurred in the El-Nino-cumwarming phase which, therefore, needs to be carefully monitored.

The remedial measures which can be actively pursued are effecting improvements in agriculture and in rural economy, according high priority to population control, initiating suitable insurance schemes, generating confidence amongst the affected people and making adequate financial provision to render relief effectively and quickly to drought-hit communities.
\end{abstract}

Keywords. Droughts; El-Nino; drought remedial measures.

\section{Introduction}

The water required for different activities in India is met mostly from rainwater provided by the summer monsoon, because a large part of the country gets most of its annual rainfall during the four monsoon months, June to September. In view of the explosive growth of population in India during the last 15 to 20 years, the demand for water has increased substantially, and the Indian economy has become vulnerable to rainfall deficiency.

Due to the high concentration of rainfall in the monsoon season, Indian droughts generally result from failure of the summer monsoon. There are three types of drought: meteorological, hydrological and agricultural. While considering meteorological 
drought, the degree of dryness is considercd in comparison to the normal rainfall. A definition of meteorological drought can be based on some specified threshold rainfall, or its anomaly. Hydrological drought follows meteorological drought and is reflected in reduced stream flow, reduced reservoir/lake levels, and reduced groundwater flow. Agricultural drought results from soil moisture deficiency. The deficiency depends on the water needs of plants and the availability of water. Agricultural drought is highly complex as the water requirements of crops depend on different stages in their growth. It varies from one crop to another.

Here, we shall consider only meteorological droughts.

\section{Factors leading to deficient monsoon rainfall}

\subsection{Global factors}

2.1 Eurasian snow cover during December to March: If the snow cover is much above normal, a part of the incoming solar radiation during April and May is used up in melting the excess snow and the remainder is used to heat the South-Asian land mass and the overlying atmosphere. Consequently, seasonal heating would be deficient and the monsoon would not develop well, resulting in deficient rain. Thus, a high snow cover would result in low monsoon rainfall. An inverse significant relationship is generally found for the period 1967-1979 between the Indian monsoon rainfall and the Eurasian snow cover from December to March as obtained from satellite data (Hahn \& Shukla 1976; Dickson 1984). But, the inclusion of later data shows some deterioration in the relationship (Mooley \& Shukla 1987, pp. 26-59). The amount of snow during December to March may serve as a better parameter. Satellites generally provide information on the area of snow cover. This parameter, however, needs to be monitored in view of its potential for adversely influencing the subsequent Indian monsoon rainfall. Satellite snow cover data are obtained from the US Climate Analysis Center.

2.1b El Nino, sea surface temperature of eastern equatorial Pacific and southern oscillation: The El Nino originates off the Peru-Ecuador coast $\left(0-12^{\circ} \mathrm{S}\right)$ in South America around Christmas time. El Nino is a Spanish word which means 'the Child'. The origin is thus associated with the birth of Christ. This phenomenon is an occasional warming off the Peru-Ecuador coast $\left(0-12^{\circ} \mathrm{S}\right)$ and results in a rise of the sea surface temperature (SST) by about $2^{\circ} \mathrm{C}$ or more above normal. It usually lasts for about a year attaining a maximum SST off the Peru-Ecuador coast around June. Quinn et al (1978) and Rasmusson \& Carpenter (1983) have tabulated El Ninos after a careful scrutiny of SST data. During 1871-1990 there were $29 \mathrm{El} \mathrm{Ninos.} \mathrm{In} \mathrm{many} \mathrm{El} \mathrm{Nino}$ years, the warming off the coast spread westwards on account of the southeast trade winds of the Southern Hemisphere.

The area-averaged seasonal SST anomaly for the large Pacific area, $0-10^{\circ} \mathrm{S} ; 80-180^{\circ} \mathrm{W}$ (eastern equatorial Pacific) was studied by Mooley \& Paolino (1989) for the period 1871-1984, using the data collected by Angell (1981) and later updated by him. Progressive warming over 3 or more seasons has been identified as a "warming phase" by them by using specific criteria. The specific criteria are: (i) total warming being $1^{\circ} \mathrm{C}$ or more, leading to attainment of an anomaly of $1^{\circ} \mathrm{C}$ or more, (ii) if the anomaly is less than $1^{\circ} \mathrm{C}$, then the SST increase should be $(1+y)^{\circ} \mathrm{C}$ or more, where 
$y$ is the amount by which the anomaly attained falls short of $1^{\circ} \mathrm{C}$. Thus, a smaller anomaly is compensated by a larger rise in SST. For example, if the anomaly is $0.3^{\circ} \mathrm{C}$, then the SST rise should be $1.7^{\circ} \mathrm{C}$ or more. With these criteria, they identified 27 warming-phase years. During 1985-90, there was one such year, namely, 1987. Thus, there are 28 warming-phase years during 1871-1990. The mean SST anomaly in warming-phase years increased from the Sept-Nov season of the preceding year to the Dec-Feb season of the year following a warming-phase year. They found that the warming phase exerts an adverse influence on monsoon rainfall. This influence is due to displacement of the equatorial vertical Walker circulation cell and its interaction with monsoon circulation. On examination of El-Nino and warming-phase years, it is found that a large number of years are El-Nino-cum-warming-phase years. The period $1871-1990$ is divided into four sets of years. The first set consists of years labelled as El-Nino-cum-warming-phase years. The second consists of warming-phase but not El-Nino years and are labelled as only warming-phase years. The third consists of El-Nino but not warming-phase years and are labelled as only El-Nino years. The fourth consists of years which are neither warming phase nor El Nino. The main features of area-averaged Indian monsoon rainfall departures in these sets of years are given in table 1 . This table also gives the rank (within and including 10), when the years are ranked on the basis of increasing departure of Indian monsoon rainfall. The main features of table 1 are as follows.

(i) El-Nino-cum-warming-phase - This set consisting of 19 years exerts a strong adverse influence on the Indian monsoon rainfall. The mean rainfall departure from normal for this set is $-13.2 \%$ with a range from $-29.0 \%$ to $0 \%$. In this set, there are 11 years with percentage rainfall departure $<-10.0 \%$. This set contains years with ranks 1 to 6 and 8. In all the years of this set, warming off Peru and Ecuador due to El Nino spreads to the whole of the eastern equatorial Pacific, and the progressive rise of SST over eastern equatorial Pacific satisfies the criteria for the warming-phase year.

(ii) Only warming phase - This set includes 9 years. Some adverse influer ce on Indian monsoon rainfall is observed. The mean percentage rainfall anomaly is -4.8 with a range from -12.0 to +2 . There are 2 years with rainfall anomaly $<-10 \%$.

(iii) Only El Nino - This includes 10 years. There appears to be no influence of an El Nino in these years on the Indian monsoon rainfall.

(iv) Neither El Nino nor warming phase - This set consists of 82 years and is a mixed set with rainfall departure ranging from $-17 \%$ to $+19 \%$. This set contains low rainfall years with ranks 7,9 and 10 . The low rainfall in the 8 years of this set is due to factors other than El Nino-warming phase or only the warming phase.

We find that while warming-phase years have a tendency to reduce Indian monsoon rainfall, it is the El-Nino-cum-warming-phase years that have a high or strong tendency to reduce the rainfall. Comparing the ranks in the El-Nino-cum-warmingphase set with those in the set of years with neither El Nino nor warming phase, we infer that an El Nino with warming phase has much higher potential for high deficiency of Indian monsoon rainfall.

In view of this situation, the El-Nino-cum-warming-phase of the eastern equatorial Pacific should be carefully monitored. The El Nino is being monitored at the US Climate Analysis Center. A watch on the warming of the Pacific region is also needed.

The Southern Oscillation is a see-saw between the atmosphere over the eastern Pacific and that over the western Pacific and the Indian Ocean. When the pressure 


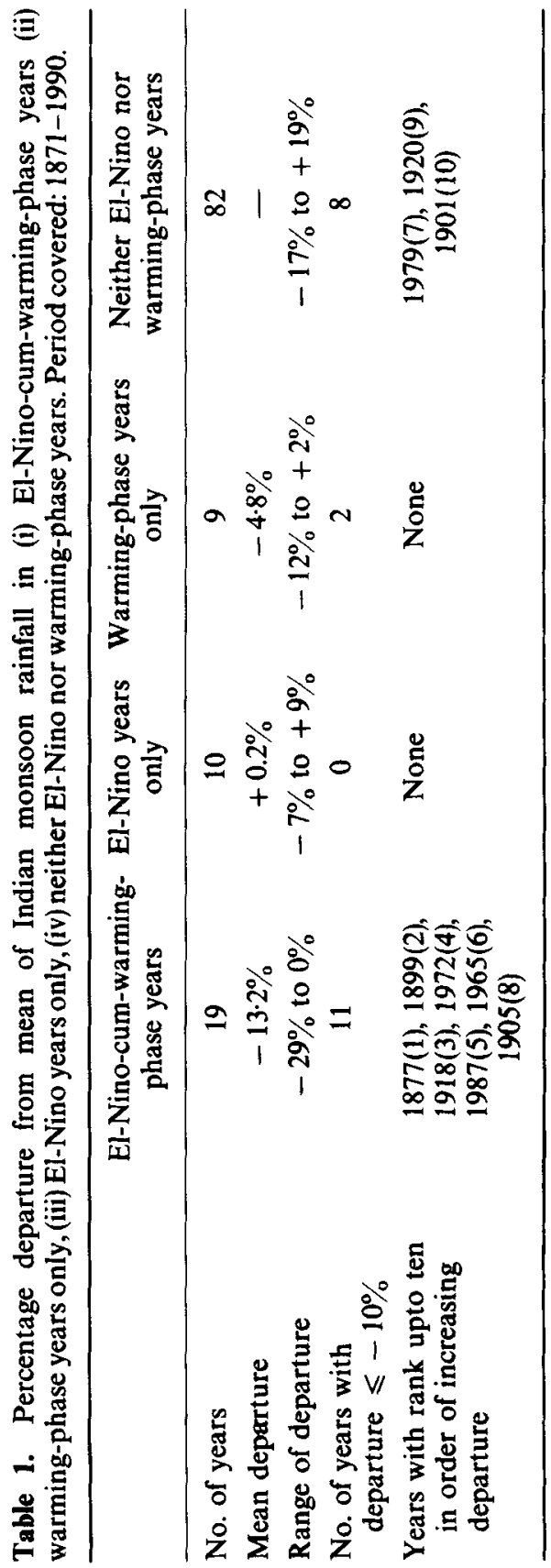


over the eastern Pacific is high that over the western Pacific and the Indian Ocean is low, and vice versa. The pressure at Darwin is often used as a measure of the Southern Oscillation Index. The Southern Oscillation and the El Nino are closely linked with each other, and the two together are referred to as the ENSO phenomenon. Sikka (1980) has brought out large-scale fluctuations in Indian monsoon rainfall in response to planetary scale features of the wind circulation of the atmosphere.

A stable and significant relationship is found between the SST tendency from the Dec-Feb to the Mar-May season, with the preceding as well as the following Indian monsoon rainfall. However, a stable and significant relationship is also found between the Southern Oscillation tendency and the following Indian monsoon rainfall over the period 1942-90 (Mooley \& Munot 1993).

\subsection{Regional factors}

2.2a Variations in the intensity and the location of the monsoon trough over India: A monsoon trough normally extends from Northeast Rajasthan to the Northwest Bay. It is a semi-permanent feature of the season. When the trough is active and is located in the normal position, the rainfall over the country is generally good and well-distributed. When the trough is weak, the rainfall is generally much less. However, when the trough shifts north to the Himalayan foothills a marked change occurs. Little rain falls over most of the country but torrential rain occurs in the subHimalayan region. Such situations are known as 'breaks' in the monsoon. A large number of days of 'breaks' reduces the rainfall appreciably.

2.2b Behaviour of westward moving low pressure systems: Lows and depressions form over the north Bay of Bengal and its neighbourhood. They generally move West or Northwest. In years of poor monsoons, these systems rarely move West of $80^{\circ} \mathrm{E}$. They are either dissipated or recurve North/Northeast before reaching this longitude. In years of good monsoon, they travel further West upto $70^{\circ}-75^{\circ} \mathrm{E}$ (Mooley \& Shukla 1989). It has been found that the total westward displacement of the low pressure systems during the whole season is significantly related to the monsoon rainfall.

\section{All-India drought}

\subsection{Criteria for all-India drought and identification of drought years}

Many workers have studied the incidence of drought over India, using different criteria. Most of them have followed the criterion that drought is an annual/monsoon season rainfall deficiency of 25\% or more (India Met. Dept. 1971; Govt. of India 1976; Koteswaram 1976).

Every year, some part of the country may experience drought. But here we consider droughts affecting a sizeable portion of India (termed All-India drought). A drought of local nature, that is, affecting a few meteorological sub-divisions or a state will not be considered here.

Kharif food production of India has a very good correlation coefficient $(0.88)$ with area-averaged Indian monsoon rainfall for the period 1966-88 (Parthasarathy et al 1992). One of the notable effects of drought is a fall in foodgrain production. Hence 
a criterion for drought based on area-averaged Indian monsoon rainfall would be reasonable. The criterion adopted is that the area-averaged Indian monsoon rainfall equals, or is less than the mean minus one standard deviation (SD). Since SD is about $10 \%$ of the mean for the area-averaged Indian monsoon rainfall, this criterion actually means that the Indian monsoon rainfall departure is equal to or less than $-10 \%$ of the mean. However, this criterion alone is not sufficient for identifying drought since adverse effects also depend on the rainfall deficiency over the different meteorological sub-divisions. Therefore, a second criterion which depends on the deficient rainfall of the sub-divisions has to be applied additionally. The effect of deficient rainfall over the different meteorological sub-divisions in a year is best integrated by considering the total Indian area under deficient monsoon rainfall. The second criterion is based on this area expressed as a percentage of the total Indian area. Now a sub-division with deficient rainfall is defined as one whose monsoon rainfall is less than or equal to mean minus SD. For each year, the sub-divisions with deficient monsoon rainfall are identified and their total area is calculated and is then expressed as a percentage of the Indian area. The percentage of deficient rainfall area criterion additionally adopted for identifying all-India drought is this deficient rainfall area $\geqslant$ (mean + SD), i.e. $\geqslant 31.4 \%$, since the mean is $15.1 \%$ and $\mathrm{SD}, 16.3 \%$. Values of percentage area under deficient rain for 1871-1990, their mean and SD as tabulated by Parthasarathy et al (1992) have been utilized. Adopting these two criteria jointly, All-India droughts during the period 1871-1990 have been identified (table 2). It can be seen that there

Table 2. Years of all-India drought along with percentage departure of Indian monsoon rainfall, and country's percentage area under deficient rainfall [drought years based on joint criteria: percentage rainfall departure $\leqslant-10 \cdot 0$; percentage area under deficient rain $\geqslant($ mean + SD) i.e. $\geqslant(15 \cdot 1+$ $16 \cdot 3)$ i.e. $\geqslant 31 \cdot 4]$.

\begin{tabular}{lcc}
\hline Year & $\begin{array}{c}\text { Rainfall } \\
\text { departure }(\%)\end{array}$ & $\begin{array}{c}\text { Area under } \\
\text { deficient rainfall }(\%)\end{array}$ \\
\hline 1873 & $-11 \cdot 4$ & $40 \cdot 9$ \\
$1877^{*}$ & $-29 \cdot 1$ & $66 \cdot 8$ \\
$1899^{*}$ & $-26 \cdot 2$ & $83 \cdot 0$ \\
1901 & $-15 \cdot 6$ & $45 \cdot 4$ \\
$1904^{+}$ & $-12 \cdot 0$ & $38 \cdot 9$ \\
$1905^{*}$ & $-16 \cdot 1$ & $40 \cdot 1$ \\
$1911^{*}$ & $-14 \cdot 0$ & $43 \cdot 5$ \\
$1918^{*}$ & $-23 \cdot 9$ & $68 \cdot 2$ \\
1920 & $-15 \cdot 8$ & $36 \cdot 5$ \\
$1941^{*}$ & $-14 \cdot 4$ & $41 \cdot 8$ \\
$1951^{*}$ & $-13 \cdot 5$ & $36 \cdot 3$ \\
$1965^{*}$ & $-17 \cdot 0$ & $43 \cdot 0$ \\
1966 & $-13 \cdot 7$ & $31 \cdot 3$ \\
$1972^{*}$ & $-23 \cdot 3$ & $49 \cdot 5$ \\
1974 & $-12 \cdot 3$ & $34 \cdot 1$ \\
1979 & $-16 \cdot 9$ & $49 \cdot 2$ \\
$1982^{*}$ & $-13 \cdot 7$ & $46 \cdot 4$ \\
$1987^{*}$ & $-19 \cdot 3$ & $64 \cdot 3$ \\
Mean & $-17 \cdot 1$ & $47 \cdot 2$ \\
\hline
\end{tabular}

area criteria marginally satisfied

Note: ${ }^{*}$ El-Nino-cum-warming-phase year; ${ }^{+}$warming-phase year only 
are 18 All-India droughts in the whole period giving an average of one drought in 6 or 7 years. The 20-year period with highest frequency of 6 is 1901-20 and the next 20-year period is 1961-80 with 5 droughts. The 40-year period 1921-60 between these two 20 -year periods has a frequency of only 2 droughts. The 20 -year period 1921-40 had no drought at all. Out of 18 droughts, 11 occurred in the years of El-Nino-cum-warming phase, one (1904) occurred in the year of the warming phase only, and none occurred in the years of $\mathrm{El} \mathrm{Nino}$ alone. There are 2 cases of successive drought years, 1904-05 and 1965-66.

We would like to classify severe and phenomenal all-India droughts. For this purpose, we have to utilise higher levels of the two criteria i.e. more stringent criteria. For severe drought, the levels of the criteria are enhanced by $50 \%$. These, on enhancement, become, percentage departure of the area-averaged Indian monsoon rainfall $\leqslant-15 \%$, and the country's area under deficient monsoon rainfall $\geqslant($ mean $+1.5 \mathrm{SD})$, i.e. $\geqslant 39.5 \%$. Utilizing these joint criteria with these levels, severe drought years have been identified. These are 1877, 1899, 1901, 1905, 1918, 1941, 1965, 1972, 1979 and 1987. There have been 10 severe droughts, giving an average of one every 12 years. Severe droughts in succession have not occurred during the entire period. All except two (in 1901 and 1979) have occurred in years of El-Nino-cum-warming phase. India experienced 2 severe droughts in the decades 1901-10 and 1971-80, none in the decades $1881-90,1921-30,1931-40$ and 1951-60 and one severe drought in each of the remaining six decades. In the years of these severe droughts the mean rainfall departure was $-18.9 \%$ and the country's mean area under deficient rain was $53.8 \%$ (more than half the country).

Utilizing still more stringent joint criteria, viz. rainfall departures $\leqslant-20 \%$ and country's area under deficient rain $\geqslant$ (mean $+2.0 \mathrm{SD}$ ) i.e. $\geqslant 47.7 \%$, for phenomenal drought, phenomenal droughts during 1871-1990 have been identified. These are $1877,1899,1918,1972$ and 1987 . There are 5 phenomenal droughts, giving an average of one in 24 years. All the five droughts occurred only in years of El-Nino-cumwarming-phase. Initially, phenomenal droughts occurred after almost 20 years. There was a long gap of 53 years after 1918. Mean rainfall departure in phenomenal droughts is $-24.4 \%$ and country's mean area under deficient rainfall is $64.4 \%$. Considering the rainfall departure and the country's area under deficient rain, the phenomenal droughts of 1877 and 1899 are the severest, both being approximately of the same severity. The 1918 drought though comparable to these two is slightly lesser in severity. Thereafter, during the last 75 years, phenomenal droughts have been relatively smaller in intensity. If a drought of the intensity of 1877 or 1899 were to occur now or in the future, the devastation would be far greater in view of the much higher level of population. There is no reason to believe that a drought of this intensity may not occur in India in future. And if it occurs, there is a high probability of its occurrence in a year with a severe El-Nino-cum-warming-phase.

\subsection{Monthly percentage Indian rainfall departure in drought years}

The monthly percentage rainfall departures for June, July, August and September are shown in figure 1. The main features of these are given below.

(i) In June, 4 years recorded positive departure $>10 \%$, the highest being $20 \%$ in 1899 and the next highest being $18 \%$ in 1911 . The lowest departure for June was $-45 \%$ in 1905 . The mean for June is $-13 \%$. 


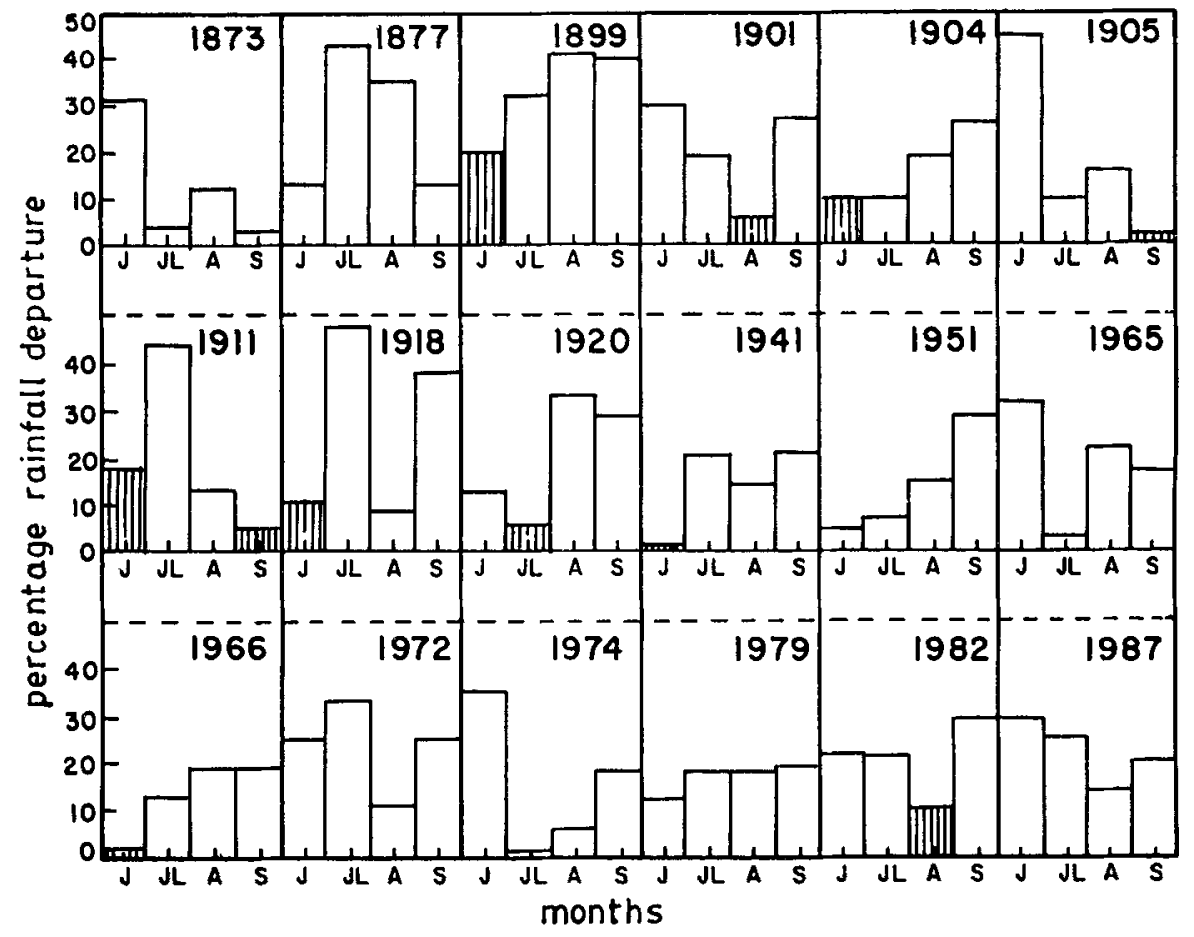

Figure 1. Percentage Indian monthly rainfall departure from normal in drought years - 10 positive $\square$ negative. Normal rainfall (mm): June 163, July 275, August 243 , September 171 , mean departure for drought years $(\%)$ June -13 , July -19 , August -16 , September -20.

(ii) In July, departure varied from $+6 \%$ in 1920 to $-48 \%$ in 1918 , with a mean of $-19 \%$.

(iii) In August, the departure varied from $+5 \%$ in 1901 to $-41 \%$ in 1899 , with a mean of $-16 \%$.

(iv) In September, the departure varied from $+5 \%$ in 1911 to $-40 \%$ in 1899 , with a mean of $-20 \%$.

In years of severe droughts, the monthly rainfall departure is $<-20 \%$ in at least two months and is negative in at least three months.

In years of phenomenal droughts the mean monthly rainfall departure is $-20 \%$ averaged over four monsoon months, and is $<-25 \%$ in July, suggesting strong contribution by this month. In 1877 and 1899, July and August, the core monsoon months, contributed strongly to the deficiency.

\section{Incidence of rainfall deficiency over different meteorological sub-divisions of India}

Here the incidence of deficiency of $>25 \%$ from normal over various sub-divisions has been considered. The probability of incidence of this deficiency has been computed for each of the sub-divisions on the basis of data for 1871-1990. This is shown in figure 2. The probability exceeds 0.30 for Saurashtra-Kutch, the westernmost sub-division of India. Harayana, Punjab, West Rajasthan and Gujarat sub-divisions 


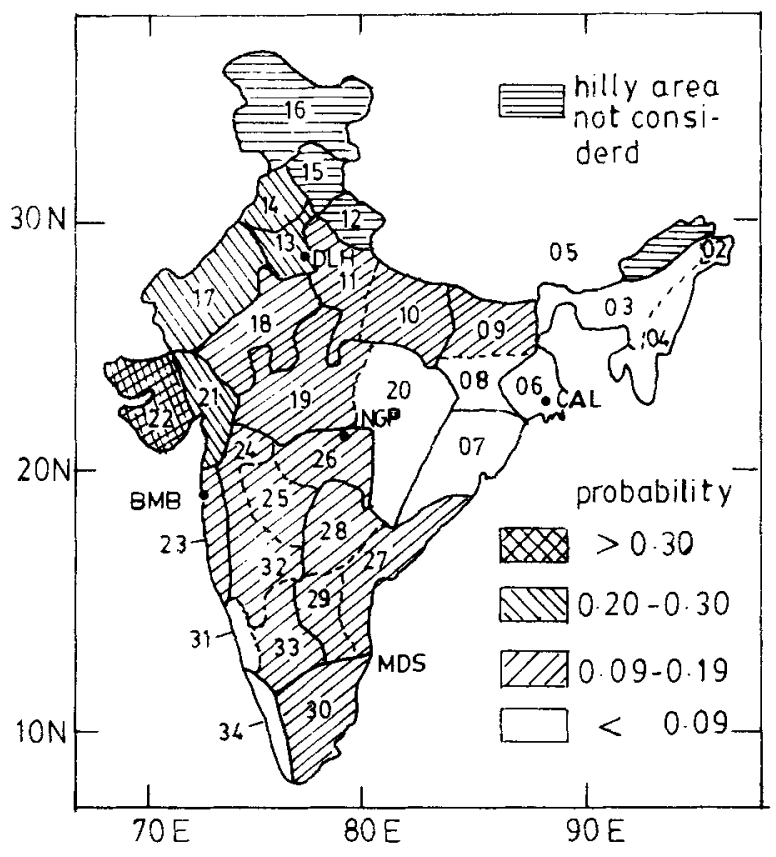

2 Arunachal Pradesh
3 North Assam
4 South Assam
5 Sub-Himalayan West Bengal
6 Gangetic West Bengai
7 Orissa
8 Bihar Plateau
9 Bihar Plains
10 East Uttar Pradesh
11 West Uttar Pradesh Plains
12 West Uttar Pradesh Hills
13 Haryana
14 Punjab
15 Himachal Pradesh
16 Jammu \& Kashmir
17 West Rajasthan
18 East Rajasthan

19 West Madhya Pradesh

20 East Madhya Pradesh

21 Gujarat

22 Saurashtra \& Kutch

23 Konkan

24 Madhya Maharashtra

25 Marathwada

26 Vidarbha

27 Coastal Andhra Pradesh

28 Telengana

29 Rayalseema

30 Tamil Nadu

31 Coastal Karnataka

32 North Karnataka

33 South Karnataka

34 Kerala

Figure 2. Empirical probability of monsoon rainfall deficiency $(\geqslant 25 \%)$ over different meteorological sub-divisions of India (1871-1990).

have a probability of 0.20 to 0.29 . Some of the eastern sub-divisions and the southern part of the West Coast have a low probability of $<0 \cdot 10$. The remaining sub-divisions have a probability of $0 \cdot 10$ to 0.19 . In general, the probability over the country decreases from west to east.

\section{Impact of drought}

Different aspects of the impact of drought over India are briefly indicated below. Due to the present explosive growth in population the impact would now be more severe. 


\subsection{Economic}

(i) Losses in production of kharif crops, dairy and livestock, fisheries and hydroelectric power.

(ii) Loss of income to farmers, farm labourers (loss of wages), Central and State Governments (revenue loss due to reduced tax base).

(iii) Shortages of (a) water for drinking, irrigation, hydro-electric power, and industry, (b) foodgrains.

(iv) Increase in price of foodgrains (by as much as $50 \%$ to $100 \%$ in drought-hit areas).

(v) Increase in rural indebtedness owing to money lenders exploiting the situation.

(vi) Incidence of epidemics. Subsistence at low levels of food-intake resulting from reduced purchasing power leads to low vitality and higher vulnerability to epidemics.

\subsection{Environmental}

(i) Damage to animal species due to lack of feed/water and due to diseases.

(ii) Wind erosion of soils.

(iii) Effect on air and water quality (due to dust and pollutants).

\subsection{Social}

(i) Exploitation of shortages by fraudulent traders.

(ii) Food riots. Those getting neither employment nor food resort to looting foodgrains to satisfy hunger.

(iii) Spread of epidemics and resulting loss of life.

\section{Remedial measures}

Remedial measures are indicated below. Some of these are already being pursued. However, to keep pace with the alarming growth of India's population, these measures will have to be pursued vigorously. Alternatively, adequate brake on population growth has to be initiated.

(I) Improvements in agriculture-

(a) increase in irrigation works/wells/tanks;

(b) sowing high-yielding and drought-resistant crop varieties;

(c) using better fertilizers, and more effective insecticides and pesticides;

(d) stepping up dry land farming.

(II) Strengthening of rural economy.

(III) Building up food reserves in rural areas also.

(IV) Improving rail/road communication in drought-prone areas.

(V) Adequate financial provisions -

Creation of a 'Natural Disaster Relief Fund' would go a long way in providing a cushion to affected communities in the aftermath of natural disasters which hit the country almost every year. A fund of this kind could be easily established through creative management of emergency allocations and donations received in the wake of natural disasters, and its existence would stimulate the evolution of longer lasting 
protection measures that would provide long-term safeguards to vulnerable communities.

(VI) Insurance-

(a) It would be advisable to introduce attractive insurance schemes to bring a large section of farmers under crop insurance;

(b) The feasibility of a scheme to cover loss of wages to farm labourers may be explored by the General Insurance Corporation of India;

(c) The feasibility of a Cattle Insurance Scheme misy be explored by the Life Insurance Corporation of India.

(VII) Suggestions for efficient drought management and for maintaining continuity of stated drought policy and of action

(a) constitution of a permanent National Disaster Relief Commission with a committee for each type of disaster:

(b) statements may be made on Drought Policy and Objectives of Drought Plan;

(c) implementation of a standard drought plan for relief to drought-hit areas should be initiated;

(d) Setting up of a monitoring unit to monitor drought conditions. For timely action in mitigating the ensuing hardship, complete coordination between the monitoring unit and all those executive officers concerned with mitigation work is essential. Timely action will inspire confidence and satisfaction among the affected population, and would make the mitigation process smooth and fast;

(e) establish a committee to identify research needs for assessment of drought and its impact;

(f) develop a training programme for personnel working for drought relief, for implementation as required;

(g) to evolve evaluation procedures for relief rendered and hardship mitigation vis-a-vis the drought plan:

(h) evaluation of each drought and preparation of a report on the same.

\section{Concluding remarks}

(i) The large Eurasian snow accumulation during December-March, the El Nino with warming phase of eastern equatorial Pacific, the long periods of 'break' in monsoon/weak monsoon trough, and poor westward penetration of monsoon lows, which have the potential to reduce monsoon rainfall substantially, need to be carefully monitored.

(ii) During 1871-1990, India experienced 18 droughts of which 10 were severe and 5 were phenomenal. While the periods $1901-20$ and 1961-80 had the highest drought incidences, the period 1921-40 experienced no drought at all. All phenomenal droughts and most of the severe droughts occurred only in the El-Nino-cum-warming-phase of the eastern equatorial Pacific.

(iii) Drought-proneness generally increases westwards.

(iv) Improvements in agriculture, strengthening of the rural economy, building up of food reserves in rural areas, some high priority measures to control population, timely action to create confidence and satisfaction amongst the affected people, suitable schemes of insurance, adequate financial provision through the creation of a permanent Natural Disaster Relief Fund, as well as of a permanent National 
Commission for Natural Disaster Relief are some of the remedial measures suggested.

The author is grateful to Dr G B Pant for providing facilities, to Dr J K Angell for the sea surface temperature data of the eastern equatorial Pacific, to Dr H N Srivastava for the monthly rainfall data of the raingauge stations, to Dr B Parthasarathy for the area-averaged rainfall of India, and to Ms S P Lakade, Ms J V Revadekar and Ms S S Nandargi for help in various forms.

\section{References}

Angell J K 1981 Comparison of variation of atmospheric quantities with sea surface temperature variations in the equatorial eastern Pacific. Mon. Weather Rev. 109: 230-243

Dickson R 1984 Eurasian snow-cover verses Indian rainfall - an extension of Hahn-Shukla results. J. Climatol. Appl. Meteor. 23: 171-173

Govt. of India 1976 Climate and agriculture. Part IV of the report of the National Commission on Agriculture, Ministry of Agriculture \& Irrigation, New Delhi

Hahn D, Shukla J 1976 An apparent relationship between Eurasian snow-cover and Indian monsoon rainfall. J. Atmos. Sci. 33: 2461-2463

India Met. Dept. 1971 Rainfall and droughts in India. Report of the Drought Research Unit, India Meteorological Department, Pune

Koteswaram P 1976 Climatological studies of droughts in Asiatic monsoon area particularly India. Proc. Indian Natl. Sci. Acad. 54: 1-14

Mooley D A, Munot A A 1993 Variation in the relationship of the Indian summer monsoon with global factors. Proc. Indian Acad. Sci. (Earth Planet. Sci.) 102: 89-104

Mooley D A, Paolini D A 1989 The response of the Indian monsoon associated with the changes in sea surface temperature over eastern south equatorial Pacific. Mausam 40: 369-380

Mooley D A, Shukla J 1987 Variability \& forecasting of the summer monsoon rainfall over India. In Monsoon meteorology (eds) C P Chang, T N Krishnamurti (Oxford: University Press)

Mooley D A, Shukla J 1989 Main features of the westward-moving low pressure systems which form over Indian region during the monsoon season and their relationship with the monsoon rainfall. Mausam 40: 137-152

Parthasarathy B, Rupa Kumar, Kothawale D R 1992a Indian summer monsoon rainfall indices: 1871-1990. Meteorol. Mag. 121: 174-186

Parthasarathy B, Rupa Kumar K, Munot A A 1992b Forecasting of rainy season foodgrain production based on monsoon rainfall. Indian J. Agri. Sci. 62: 1-8

Quinn W H, Zoff D O, Short K S, Kuo Yang R T W 1978 Historical trends and statistics of Southern Oscillation, El Nino and Indonesian Droughts. Fish. Bull. 76: 663-678

Rasmusson E M, Carpenter T H 1983 The relationship between eastern equatorial Pacific sea surface temperature and rainfall over India and Sri Lanka. Mon. Weather Rev. 111: $517-528$

Sikka D R 1980 Some aspects of large-scale fluctuations of summer monsoon rainfall over India in relation to fluctuations in the planetary and regional scale circulation parameters. Proc. Indian Acad. Sci. (Earth Planet. Sci.) 89: 179-195 